\title{
ANALISIS STRUKTUR RETORIKA DAN FITUR LINGUISTIK BAGIAN PENDAHULUAN ARTIKEL JURNAL PENELITIAN BERBAHASA INDONESIA DALAM BIDANG ILMU KEDOKTERAN DAN KESEHATAN
}

\author{
Lexpya Sepni
}

sepni.lexpya@yahoo.com

\begin{abstract}
The purpose of this study was to describe the structure of the rhetoric of the introductory part of the research journal articles in Indonesian language. Linguistic features the introduction Indonesian language research journal articles in the field of medical science and health. This research uses descriptive method. Source of this research are 50 articles while the data in the form of research journal articles in the field of medical science and health. Data collection techniques are documents such as speech writer in the text of the discourse, data analysis techniques to read and memberian code of the article, the findings of this study analyzed the structure of rhetoric uses the theory of MMP which consists of 4 stages and 18 steps, while the feature linguistics is defined as the use of the type or variety text associated with active and passive sentences, types of clauses, conjunctions / circuit. The research result rhetorical structure analysis introductory part AJP in the field of medicine and health, such as the use of the stages and steps are found or used in a rhetorical structure AJP field of medical science and health with the result that most of the stages of T-2 to justify the research topic. While the use measures in stages in the field of medicine and health: (1) step T2-LC merefiu related literature, (2) a step T1$L D$ describe lok ation of geographic research, (3) a step T4-LA explain the purpose of the study, which the last (fourth) step T3-LD expressed interested in examining the issue. Furthermore, linguistic features found in the introductory part of AJP in the field of medical science and health, among others: (1) active and passive sentences, (2) coordination, (3) the subordinate attributes.
\end{abstract}

Keywords: structure, rhetoric, linguistic features, Research Journal article

\section{PENDAHULUAN}

Artikel jurnal penelitian bagian pendahuluan dalam bidang ilmu kedokteran dan kesehatan banyak diminati oleh para peneliti Indonesia untuk diteliti dan dianalisis dalam berbahasa Indonesia atau berbahasa Inggris. Bagian pendahuluan pada artikel jurnal penelitian di bidang ilmu kedokteran dan kesehatan merupakan bentuk dari suatu pernyataan dari kasus yang diselidiki. Artikel jurnal penelitian memberikan informasi kepada pembaca untuk tujuan spesifikasi dalam kerangka teoritis bersifat ilmu pengetahuan dalam bidang analisis jurnal penelitianbidang ilmu kedokteran dan kesehatan.

Artikel jurnal ialah artikel yang dibuat berdasarkan penelitian atau pemikiran untuk dimuat dalam jurnal ilmiah atau majalah ilmiah. Artikel jurnal termasuk karangan ilmiah karena merupakan bentuk karya tulis yang disusun berdasarkan metode ilmiah (Susetyo, 2009:22).

Belcher (dalam Safnil 2014: 74), menjelaskan bahwa tujuan utama 
pendahuluan adalah untuk memberi informasi yang cukup bagi para pembaca untuk dapat memahami argumen yang dikembangkan dalam artikel hasil penelitian tersebut. Seperangkat tujuan komunikasi dalam AJP sebelumnya sudah standar dan dipahami masyarakat akademik secara luas. Gilbert (1976) berpendapat bahwa AJP telah digunakan untuk mengsosialisasikan sebuah kegiatan penelitian untuk menyakinkan pembaca bahwa hasil penelitian tersebut layak dan perlu dibaca.

Safnil, (2014: 79) menyatakan bahwa gaya retorika bagian pendahuluan AJP memiliki tahapan (moves) dan langkah (steps). Tahapan- 1 estabilising a territory dalam pendahuluan AJP berbahasa Indonesia disampaikan dengan cara mengacu pada kebijakan pemerintah atau masalah praktis dilapangan untuk menyakinkan pembaca bahwa topik penelitian tersebut penting. Tahapan- 2 (establishing niche) adalah tahapan ini penulis harus menyakinkan pembaca bahwa kegiatan penelitian mereka sangat penting. Pola retorika yang memperkenalkan bagian pendahuluan artikel jurnal penelitian mempunyai tiga sub bagian tahapan (move) atau unit komunikatif dengan fungsi yang berbeda-beda dan dalam masing-masing tahapan juga terdapat satu atau lebih langkah atau unit komunikatif lebih kecil yang bertujuan untuk menjabarkan lebih rinci setiap tahapan agar lebih mudah dikomunikasikan.

Berdasarkan uraian tersebut, alasan peneliti menganalisis struktur retorika dan fitur lingustik bagian pendahuluan artikel jurnal penelitian (AJP) dalam berbahasa Indonesia dalam bidang ilmu kedokteran dan kesehatan begitu penting memberikan pemahaman terhadap karya ilmiah. Penting maksudnya dapat menjadi bahan masukan bagi mahasiswa untuk dapat mencoba untuk menganalisis dan memahami struktur retorika dan fitur linguistik dalam berbagai bidang ilmu. Alasan kedua peneliti ialah pada bagian pendahuluan artikel jurnal penelitian dalam bahasa Indonesia belum pernah diteliti dalam struktur retorika dan fitur linguistiknya. Dari alasan tersebut maka peneliti melakukan penelitian deskriptif dengan judul "Analisis Struktur Retorika dan Fitur Linguistik Bagian Pendahuluan Artikel Jurnal Penelitian Berbahasa Indonesia Dalam Bidang IImu Kedokteran dan Kesehatan."

\section{METODE PENELITIAN}

Metode yang digunakan dalam penelitian ini ialah metode penelitian deskriptif yang bertujuan untuk mendeskripsikan pola retorika dan fitur lingustik artikel bagianpendahuluan. Sumber data penelitian ini adalah 50 artikel jurnal penelitian dalam bidang kedokteran dan kesehatan. Sedangkan data dalam penelitian ini adalah tuturan penulis berupateks wacana artikel jurnal penelitian sebagai berikut: Majalah kedokteran Bandung vol.42 no. 1. 2010, majalah kedokteran Bandung vol.42 no.2. 2010, jurnal kesehatan masyarakat nasional. Vol. 5 no. 1. 2010, majalah kedokteran Bandung vol. 43 no. 3. 2011, jurnal kesehatan masyarakat nasional vol. 6 no. 6. 2011, jurnal kesehatan vol. 10 no. 2. 2012, jurnal kesehatan bina husada vol. 9 no. 1. 2013.

Teknik pengumpulan data yang digunakan dalam penelitian ini adalah dokumentasi artikel jurnal penelitian 
bidang ilmu kedokteran dan kesehatan.Instrumen penelitian untuk analisis fitur linguistik menggunakan ceklis data yang berisi tentang kalima aktif dan pasif, jenis anak kalimat, kata sambung/hubung. Ada pun kisi-kisi dalam struktur retorika dan fitur lingustik dalam menganalisis bagian pendahuluan artikel jurnal penelitian dalam bidang ilmu kedokteran dan kesehatan, dengan memperhatikan aspek struktur retorika, dan fitur linguistiknya. Teknik yang digunakan untuk pemeriksaan keabsahan data dalam penelitian ini adalah dengan menggunakan teknik trianggulasi.

\section{HASIL DAN PEMBAHASAN}

\section{A. Hasil Penelitian}

Retorika dari 50 artikel yang dianalisis khusunya bagian pendahuluan AJP berbahasa Indonesia dalam bidang ilmu kedokteran dan kesehatan dapat dideskripsikan sebagai berikut: Tahapan menyamakan latar belakang pengetahuan disebut (tahapan 1) tahapan ini menjelaskan tentang konsep dasar terciptanya sebuah penelitian. Artikel jurnal penelitian dalam bidang ilmu kedokteran dan kesehatan menyajikan gambaran umum tentang latar belakang pengetahuan yang ditelitinya sehingga peneliti membuat pernyataanbersifat argumentasi, ini dilihat melalui kutipan sebagai berikut:

" Indonesia, negara penghasil teh terbesar kelima setelahIndia, China, Srilanka dan Kenya, tetapi konsumsi teh Indonesia masih tergolong rendah $(0,2 \mathrm{k}$ kg/kapita/tahun)."(AJP 6)

Tahapan menjastifikasi topik penelitian ( tahapan 2) tahapan ini, mengenal topik apa yang dibahas, masalah-masalah apa saja yang akan diselesaikan, ini dilihat melalui kutipan sebagai berikut:

"Radioterafi merupakan pilihan utama terafi karsinoma nasofaring karena bersifat radiosensitif terutama untuk jenis karsinoma yang kurang berdiferensial."(AJP 8)

Tahapan menjastifikasi kegiatan penelitian, (tahapan 3) tahapan ini memberikan informasi apa saja yang didapatkan dan masalah oleh peneliti ini dilihat melalui kutipan sebagai berikut: "Meskipun belum sepenuhnya terbukti beberapa penelitian terdahulu menunjukkan pengaruh genotipe VHB pada manifestasi klinis." (AJP 15)

Tahapan mengumumkan kegiatan penelitian (tahapan 4) tahapan ini menjelaskan dan mendeskripsikan penelitian ini dilihat melalui kutipan sebagaia berikut:"Tujuan pada penelitian ini adalah untuk menguji jumlah eosionupil pada kerokan mukosahidin dibandingkan dengan tes kulit tusuk."(AJP 2).

\section{Langkah Struktur Retorika}

Tahapan yang ada struktur retorika terbagi menjadi 18 langkah, dengan diberi kode tahapan 1 menyamakan latar belakang pengetahuan antara lain: (T1-LA) mendefenisikan istilah penting, (T1-LB) mengacu kepada kebijakan pemerintah, (T1-LC) menjelaskan sejarah singkat bidang penelitian, (T1-LD) mendeskripsikan lokasi geografis penelitian. Tahapan 2 antara lain menjastifikasi topik penelitian (T2-LA) memperkenalkan topik penelitian, (T2LB) mengidentifikasi masalah penelitian, (T2-LC) merefiu literatur terkait. Tahapan 3 antara lain; (T3-LA) menunjukan 
kesenjangan informasi tentang topik penelitian, (T3-LB) menyatakan bahwa penelitian tersebut belum pernah diteliti, (T3-LC) menyatakan bahwa topik tersebut penting diteliti, (T3-LD) menyatakan tertarik meneliti masalah tersebut. Tahapan 4 antara lain (T4-LA) menjelaskan tujuan penelitian, (T4-LB) me nyatakan pertanyaan penelitian, (T4LC) mendeskripsikan ciri-ciri khusus penelitian, (T4-LD) menyatakan manfaat penelitian, (T4-LE) mengumumkan temuan penelitian, (T4-LF) menyatakan hipotesis penelitian.

\section{Fitur Lingustik}

Fitur lingustik merupakan jenis atau macam gaya bahasabaik berupa kalimatdan paragraf yang digunakan secara lisan maupun tulisan sebagai sarana komunikasiuntuk menyampaikan fikiran atau gagasan kepadaorang lain agar dapat dipahami dengan mudah.

Bagian pendahuluan artikel jurnal penelitian dalam bidang ilmu kedokteran dan kesehatan, yang digunakan sebagai teks wacana artikeljurnal penelitian sebagai penanda komunikatif, antara lain: (1) kalimat aktif dan pasif, (2) jenis anak kalimat menyatakan waktu, keterangan sebab, keterangan hasil (akibat), keterangan syarat, keterangan tujuan, keterangan cara, (3) penggunaan kata sambung/hubung.

Tabel Tahapan dalam pendahuluan AJP berbahasa Indonesia

\begin{tabular}{|c|c|c|c|}
\hline Tahapan & Tujuan & Jumlah & Persentase \\
\hline 1 & $\begin{array}{c}\text { Menyamakan latar belakang } \\
\text { pengetahuan }\end{array}$ & 49 & $98 \%$ \\
\hline 2 & Menjastifikasi topik penelitian & 50 & $100 \%$ \\
\hline 3 & Menjastifikasi kegiatan penelitian & 14 & $28 \%$ \\
\hline 4 & Mengumumkan kegiatan penelitian & 45 & $90 \%$ \\
\hline
\end{tabular}

Berdasarkan hasil jumlah dan persentasi dari tabel 4.1 mengenai jumlah dan persentase tahapan, terlihat bahwa jumlah dan persentase . tahapan 1, 2 dan 4 memilki jumlah yang tidak jauh berbeda. Tahapan terakhir pada tahapan 3 artikel jurnal penelitian sebanyak 14 artikel jurnal dengan persentase $28 \%$ hanya sedikit ditemukan pada AJP berbahasa Indonesia bidang ilmu kedokteran dan kesehatan dibandingkan dengan tahapan 1, 2, dan 4.

\section{Fitur Linguistik}

Fitur linguistik yangdiperhatikan peneliti adalah penggunaan kata kerja seperti dalam mengutip referensi (secara langsung atau tidak langsung) dalam teks ilmiah. Swales (dalam Safnil dan Wardhana, 2013: 17), misalnya, diklasifikasikan dua cara yang berbeda kutipan yang umum ditemukan dalam teks ilmiah: integral dan non-integral dan enammodel yang berbeda pada masingmasing klasifikasi. Namun, perbedaan yang lebih penting adalah antara penggunaan kutipan pelaporan dan nonpelaporan. Menurut Swales, pilihan antara bentuk pelaporan dan non- 
pelaporan dalam kutipan memiliki fungsi retorika yang penting, yaitu untuk menciptakan ruang penelitian bagi peneliti.

Selain untuk menganalisis struktur retorika artikel jurnal berbahasalndonesia dalam bidang ilmu kedokteran dan kesehatan, penelitian ini juga meneliti tentang penggunaan.fitur aktif danpasif, jenis anak kalimat, katasambung/hubung.

\section{Penggunaan Kalimat Aktif dan Pasif}

Kalimat aktif dan kalimat pasif dimana kedua kalimat tersebut merupakan komponen dalam fitur linguistik yang digunakan untuk memahami dan menganalisis sebuah artikel jurnal penelitian bagian pendahuluan.Karena kalimat aktif dan pasif merupakan penanda linguistik dalam wacana sehingga lebih komunikatif dalam sebuah teks. Dari penjelasan kalimat aktif dan pasif tersebut dalam fitur linguistik yang terdapat dalam artikel jurnal penelitian.

Tabel penggunaan kalimat aktif dan kalimat pasif sebagai berikut:

\begin{tabular}{|c|l|c|c|}
\hline No & \multicolumn{1}{|c|}{$\begin{array}{c}\text { Jenis } \\
\text { kalimat }\end{array}$} & F & $\begin{array}{c}\text { Persentase } \\
(\%)\end{array}$ \\
\hline 1 & $\begin{array}{l}\text { Kalimat } \\
\text { Aktif }\end{array}$ & 584 & $47 \%$ \\
\hline 2 & $\begin{array}{l}\text { Kalimat } \\
\text { Pasif }\end{array}$ & 660 & $53 \%$ \\
\hline 3 & Jumlah & 1244 & $100 \%$ \\
\hline
\end{tabular}

Berdasarkan tabel diatas dapat dilihat bahwa penggunaan kalimat aktif lebih sedikit dibandingkan penggunaan kalimat pasif yaitu 584 pada kalimat aktif dengan persentase 47\%, sedangkan 660 pada kalimat pasif dengan persentase $53 \%$. Kalimat aktif merupakan kalimat yang subjeknya melakukan pekerjaan atau melakukan perbuatan. Contoh penggunaan kalimat aktif dapat dilihat dari beberapa kutipan berikut:

(1) " Data tersebut menunjukan tingginya angka insedensi rinitis alergi pada usia sekolah dan produktif." (AJP 2)

(2) "Adanya mutasi dari gen-gen tersebut dapat mengakibatkan keganasan kolorektal. Pada tahun 1990, Fearon dan Vogelstein, seperti dikutip oleh Kelli, memperkenalkan patogenis terjadinya karsinoma kolorektat." (AJP 3)

(3) "Sumber Biro Pusat Statistik (BPS) 2004 menyebutkan bahwa angka kematian bayi (AKB) di Indonesia masih tertinggi di wilayah negara ASEAN." (AJP 4)

Selanjutnya adalah penggunaan kalimat pasif. Kalimat pasif merupakan kalimat yang subjeknya dikenai pekerjaan atau dikenai perbuatan. Penggunaan kalimat pasif lebih banyak dibandingkan penggunaan kalimat aktif yaitu sebanyak 660. Total tersebut diperoleh berdasarkan 50 artikel jurnal ilmiah berbahasa Indonesia bidang ilmu kedokteran dan kesehatan. Contoh penggunaan kalimat pasif tergambar melalui kutipan berikut:

(1) "Brachial plexus palsy merupakan suatu paralisis yang diakibatkan oleh cedera pada sebagian atau seluruh pleksus brakialis. Brachial plexus palsy pada bayi baru lahir disebabkan cedera." (AJP 5)

(2) " Pada laporan penelitian Ciraj dkk ditemukan adanya aktivitas antibakteri eksteraks alkohol teh hitam terhadap Salmonella typhi pada konsentrasi $2 \%$. (AJP 6)

(3) "Pada dekade terkhir, penyakit ini ditemukan hampir di seluruh belahan dunia . pada populasi kulit putih di Amerika Utara dan Eropa jarang ditemukan karsinoma nasofaring." (AJP 8) 
Berdasarkan hasil perhitungan pada tabel 4.5 jumlah penggunaan kalimat aktif dan kalimat pasifterdapat perbedaan jumlah masing-masing artikel dengan persentase yang berbeda pula.

\section{Penggunaan Konjungsi dalam Bagian Pendahuluan AJP}

Selain penggunaan kalimat aktif dan pasif, fitur linguistik lainya adalah penggunaan konjungsi dalam kalimat. Penggunaan konjungsi tersebut terbagi menjadi tiga bagian subordinatif. Untuk konjungsi subordinatif hanya tiga belas jenis konjungsi subordinatif tujuan, konjungsi subordinatifsyarat, konjungsi subordinatif waktu, konjungsi subordinatif alat, konjungsi subordinatif hasil, konjungsi subordinatif sebab, konjungsi subordinatif perbandingan, konjungsi subordinatifkonsesif, konjungsi subordinatif attributif, konjungsi subordinatif komplementasi, konjungsi subordinatif cara, dan korelatif.

Tabel Penggunaan Konjungsi

\begin{tabular}{|c|c|c|c|}
\hline \multicolumn{4}{|c|}{ KONJUNGSI N=50 AJP KEDOKTERAN DAN KESEHATAN } \\
\hline \multicolumn{2}{|c|}{ KONJUNGSI } & JLH AJP & PERSENTASE \\
\hline \multirow{3}{*}{ KOORDINATIF } & Penambahan & 50 & $100 \%$ \\
\hline & Pendampingan & 29 & $58 \%$ \\
\hline & Pemilihan & 30 & $60 \%$ \\
\hline & Perlawanan & 18 & $36 \%$ \\
\hline & Pertentangan & 17 & $34 \%$ \\
\hline \multirow{2}{*}{ SUBKOORDIBATIF } & Tujuan & 1 & $2 \%$ \\
\hline & Syarat & 7 & $14 \%$ \\
\hline & Waktu & 26 & $52 \%$ \\
\hline & Alat /cara & 47 & $84 \%$ \\
\hline & Hasil & 27 & $54 \%$ \\
\hline & Sebab & 26 & $52 \%$ \\
\hline & Perbandingan & 4 & $8 \%$ \\
\hline & Konsesif & 1 & $2 \%$ \\
\hline & Attributif & 50 & $100 \%$ \\
\hline & Komplementasi & 36 & $72 \%$ \\
\hline & & 0 & $0 \%$ \\
\hline & & & \\
\hline
\end{tabular}

Berdasarkan tabel diatas dapat disimpulkan bahwa dari hasil perhitunganpenggunaan konjungsi koordinatif dalam kalimat ditemukan bahwa penggunaan konjungsi koordinatif dan konjungsi atribut yang hampir dimiliki oleh semua artikel jurnal penelitian berbahasa Indonesia bidang ilmu kedokteran dan kesehatan dengan jumlah masing-masing 50artikel penelitian sesuai dengan tabel diatas dengan persentase yang berbeda-beda. Kutipan penggunaan konjungsi koordinatif adalah sebagai berikut:

(1) "Salmonella typhi sebagai penyebab demam tifoid yang masih merupakan masalah kesehatan masyarakat dan penyebab utama morbiditas di negara tropis. (AJP 6) 
(2) Peningkatan ekspresi protein proapoptosis p53 dan Bax, serta berkurangnya ekspresi protein.(AJP1)

(3) Masalah GAKY merupakan masalah serius mengingat dampaknya secara langsung atau tidak langsung mempengaruhi kelangsungan hidup dan kualitas sumber daya manusiayang mencakup 3 aspek, yaitu aspek perkembangan kecerdasan, aspek perkembangan social, aspek perkembangan ekonomi. (AJP11).

Kutipan penggunaan konjungsi pada artikel kedokteran dan kesehatan yang ditemukan. Kutipan konjungsi subordinatif dapat dilihat sebagai berikut:

(4) " Media perbenihan sangat penting untuk isolasi bakteri. Media perbenihan hingga saat ini masih diimpor dengan harga yang semakin mahal akibat krisis ekonomi. Oleh karena itu, upaya untuk mencari media alternatif lain perlu dilakukan guna mengurangi ketergantungan terhadap media impor." (AJP17)

(5) " Adanya peningkatan kadar NSE dalam cairan serebrospinal dan serum darah penderita infrark serebri akut. (AJP7)

(6) "Bahwa negara berusaha untuk memenuhi hak anak yang juga merupakan komitmen internasional bagaimana dunia yang aman bagi anak dengan prinsip pokok perlindungan dan kesejehteraan anak maka terselenggara Lembaga atau Komisi Perlindungan anak. (AJP26)

Penggunaan konjungsi dalam kalimat memiliki peranan dalam kerberhasilan sebuah tulisan, karena konjungsi memiliki fungsi menghubungkan antar kalimat agar mudah dimengerti.

\section{B. Pembahasan}

Pada AJP berbahasa Indonesia berbeda dengan AJP berbahasa Inggris yang tidak memiliki tahapan pertama yaitu menyamakan latar belakang pengetahuan, selanjutnya pola retorika yang diberi nama masalah menjastifikasi penelitian (MMP) yang diadopsi dari model CARS dari Swales (1990). Model MMP menurut Safnil, (2010: 89) juga mengadopsi suatu pandangan yang didasarkan pada hubungan bentuk fungsi; empat (tahapan) move komunikatif, misalnya mengambarkan tujuan komunikatif dari pendahuluan retorika artikel bidang ilmu kedokteran dan kesehatan dengan sub tahapan, yangdisebut langkah (step), sebagai bentuk retorika.

Model Masalah Menjastifikasi Penelitian (MMP) dalam kutipan langsung, terdiri dari empat tahapan: (1) menyamakan latar belakang pengetahuan, (2) menjastifikasi topik penelitian, (3) menjastifikasi kegiatan penelitian, (4) mengumumkan kegiatan penelitian. Selanjutnya, dalam setiap langkah ada beberapa tahapan dimana penulis retorika dapat menggunakannya untuk mencapai tujuan komunikatif utama dari langkah menurut Safnil, (2014: 84).

Teori MMP yang dikembangkan oleh Safnil yang menjelaskan bahwa teori MMP yang ditemukan dalam artikel bidang ilmu kedokteran dan kesehatan ini terdari dari 4 tahapan dan 18 langkah. Namuntidak ditemukan beberapa tahapan. Pada tahapan 2 menjastifikasi topik penelitian ditemukan semua langkah dengan jumlah 50 artikel dengan persentase $100 \%$ dibandingkan dengan tahapan yang lainnya seperti tahapan 1 
menyamakan latar belakang pengetahuan dengan jumlah 49 artikel dengan persentase $98 \%$, selanjutnya tahapan 4 mengumumkankegiatan penelitian 45 artikel dengan jumlah persentase $90 \%$ dan yang terakhir tahapan 3 menjastifikasi kegiatan penelitian dengan 14 artikel dengan jumlah persentase $28 \%$ paling kecil diantara tahapan lain.

Pada tahapan 2 dalam langkah T2-LC menunjukkan bahwa langkah tersebutbanyak dijumpai dalam artikel jurnal penelitian berbahasa indonesia dalam bidang ilmu kedokteran dan kesehatan yang menyatakan langkah T2LC merefiu literatur terkait. Langkah T2LC lebih dominan paling banyak dijumpai dibandingkan pada langkah-langkah lain dalam tahapan T2-LC. Hal yang membuat langkah T2-LCini lebih dominan disebabkan peneliti ingin menyakinkan para pembaca dengan merefiu literatur terkait sehingga pembaca lebih termotivasi untuk membacanya dengan adanya pakar dari sumber terpercaya menurut beberapa ahli.

Pada proses tahapan dan langkah, juga dianalisis tentang fitur linguistik dalam sebuah tulisan artikel. Berdasarkan hasil analisis dapat disimpulkan bahwa didalam artikel jurnal penelitianberbahasa indonesia bidang ilmu kedokteran dan kesehatan cenderung lebih banyak menggunakan kalimat aktif dibandingkan penggunaan kalimat pasif. Fitur linguistik tidak terlepas dari kalimat dan paragraf, dimana kalimat dan paragraf penting baik lisan maupun tulisan. Kalimat merupakan sarana komunikasi untuk menyampaikan pikiran atau gagasan kepada orang lain agar dapat dipahami dengan mudah. Untuk itu, kalimat harus disusunsesuai dengan struktur yang benar, pengunaan gagasan dengan baik, singkat, tepat, jelas, maknanya dan santun.

Widjono,

(2011:

mengemukakan bahwa kalimat adalah bahasa terkecil yang merupakan kesatuan pikiran dalam bahasa lisan kalimat diawali dan diakhiri dengan kesenyapan, dan dalam bahasa tulis diawali dengan huruf kapital dan akhiri dengan tanda titik, tanda seru, dan tanda tanya.

Penggunaan kalimat dalam artikel ilmiah berupa kalimat ragam tulis baku. Kalimat ragam tulis baku hendaknya berupa kalimat yang efektif (Susetyo, 2009: 45) yang terdiri dari 1 subjek tidak didahului kata dengan dan dalam, 2 kata sedangkan dan sehingga tidak digunakan dalam kalimat tunggal, 3 subjek kalimat tidak boleh satu, 4 kesejaran bentuk kata.

Kalimat aktif maupun kalimat pasif dapat mempengaruhi keefektifan dalam kalimat atau wacana. Kalimat yang benar dan jelas dengan mudah dipahami orang lain secara tepat. Keefektifansebuah kalimat menjadi persoalan bagaimana sebuah kalimat dapat secara tepat mewakli isi pikiran atau perasaan seseorang, dan bagaimana kalimat itu dapat disajikan secara benar dan semenarik mungkin terhadap pembaca atau pendengar terhadap apa yang dibicarakan. Hal ini berarti kalimat efektif harus disusun secara tepat untuk mencapai informasi yang diinginkan terhadap pembacanya.

Kalimat aktif dan kalimat pasif merupakan komponen dalam fitur linguistik yang digunakan untuk memahami dan menganalisis sebuah artikel jurnal penelitian bagian 
pendahuluan.Tjiptadi dan Negoro, (1985: 48) kalimat aktif adalah kalimat yang subjeknya melakukan suatu perbuatan.Kalimat aktif ini predikatnya harus kata kerja atau predikatnya verbal.Sedangkan kalimat pasif adalah kalimat yang subjeknya dikenai oleh perbuatan.

Berdasarkan hasil analisis data tentang penggunaan konjungsi dalam artikel, dapat disimpulkan bahwa penggunaan konjungsi koordinatif seperti kata dan, serta, atau, sedangkan dan lainnya ditemukan. Konjungsi subkoordinatif ditemukan semua dalam artikel seperti kata saat, hingga, yang, dan lainnya tetapi pada korelatif tidak ditemukan sama sekali pada artikel AJP Berdasarkan hasil analisis data tentang penggunaan konjungsi dalam artikel, dapat disimpulkan bahwa penggunaan konjungsi koordinatif seperti kata dan, serta, atau, sedangkan dan lainnya ditemukan. Konjungsi subkoordinatif ditemukan semua dalam artikel seperti kata saat, hingga, yang, dan lainnya tetapi pada korelatif tidak ditemukan sama sekali pada artikel jurnal penelitian berbahasa Indonesia bidang ilmu kedokteran dan kesehatan. Dapatjuga disimpulkan bahwa struktur retorika tahapan 1 menyamakan latar belakang pengetahuan berjumlah 49 dengan persentase $98 \%$, pada tahapan 2 menjastifikasi topik penelitian berjumlah 50 dengan persentase $100 \%$, selanjutnya tahapan 3 menjastifikasi kegiatan penelitian berjumlah 14 dengan persentase $28 \%$ yang terakhir tahapan 4 mengumpulkan kegiatan berjumlah 45 dengan persentase $90 \%$. Pada tahapan 1 , 2, 4 memiliki nilai yang tidak jauh berbeda hampir sama nilainya dibandingkan dengan tahapan 3 cukup subjektif menjastifikasi kegiatan penelitian meskipun jumlah nilainya sedikit. Beberapa usulan pola revisi terhadap pjp bidang ilmu kedokteran dan kesehatan sebagai berikut; Tahap 1: Menyamakan latar belakang pengetahuan (mendefinisikan istilah penting, menjelaskan sejarah singkat bidang penelitian, dan mendeskripsikan lokasi penelitian. Tahap 2: Menjastifikasi topik penelitian (memperkenalkan topik penelitian, mengidentifikasi masalah penelitian, dan merefiu literatur terkait). Tahap 3: Menjastifikasi kegiatan penelitian, tidak ditemukan kajian yang menggunakan tahapan ini. Tahap 4: Mengumumkan kegiatan penelitian (menjelaskan tujuan penelitian).

\section{SIMPULAN}

Berdasarkan hasil penelitian dan pembahasan dapat disimpulkan bahwa struktur retorika bagian pendahuluan AJP dalam bidang ilmu kedokteran dan kesehatanmenggunakan teori MMP terdapat struktur retorika tersebut terdiri dari 4 tahapan: (1) menyamakan latar belakang pengetahuan, menjastifikasi topik penelitian, menjastifikasi kegiatan penelitian, (4) mengumumkan kegiatan penelitian.

Tahapan yang ada dalam struktur retorika, setiap tahapan memiliki langkah-langkah menjadi 18 langkah, menyamakan latar belakang pengetahuan tahapan 1 memiliki langkah-langkah antara lain: (T1-LA) mendefenisikan istilah penting, (T1-LB) mengacu kepada kebijakan pemerintah, (T1-LC) menjelaskan sejarah singkat bidang penelitian, (T1-LD) mendeskripsikan lokasi geografis penelitian, menjastifikasi topik penelitian 
tahapan 2 memiliki langkah-langkah antara lain; (T2-LA) memperkenalkan topik penelitian, (T2-LB) mengidentifikasi masalah penelitian, (T2-LC) merefiu literatur terkait, menjastifikasi kegiatan penelitian tahapan 3 memiliki langkahlangka antara lain;(T3-LA) menunjukan kesenjangan informasi tentang topik penelitian, (T3-LB) menyatakan bahwa penelitian tersebut belum pernah diteliti, (T3-LC) menyatakan bahwa topik tersebut penting diteliti, (T3-LD) menyatakan tertarik meneliti masalah tersebut, mengumumkan kegiatan penelitian tahapan 4 memiliki langkahlangkah antara lain: (T4-LA) menjelaskan tujuan penelitian, (T4-LB) menyatakan pertanyaan penelitian, (T4-LC) mendeskripsikan ciri-ciri khusus penelitian, (T4-LD) menyatakan manfaat penelitian, (T4-LE) mengumumkan temuan penelitian, (T4-LF) menyatakan hipotesis penelitian.

Fitur lingustik bagian pendahuluan artikel jurnal penelitian dalam bidang ilmu kedokteran dan kesehatan, yang digunakan sebagai teks wacana artikeljurnal penelitian sebagai penanda komunikatif, antara lain: (1) kalimat aktif dan pasif, (2) jenis anak kalimat menyatakan waktu, keterangan sebab, keterangan hasil (akibat), keterangan syarat, keterangan tujuan, keterangan cara, (3) penggunaan kata sambung/hubung.

\section{SARAN}

Berdasarkan penelitian yang ditemukan terdapat saran-saran yang berkaitan dengan pemanfaatan hasil penelitian, sebagai berikut:

(1) Bagi mahasiswa, guru, dan dosen, sebagai masukan dalam memahami struktur retorika dan fitur linguistik bagian artikel jurnal penelitian berbahasa Indonesia dalam bidang ilmu kedokteran dan kesehatan serta menambah wawasan dalam menyusun dan menulis bagian artikel jurnal penelitian.

(2) Bagi peneliti lanjutan, sebagai bahan masukan dalam memperdalam wawasan dan menambah literatur pengetahuan tentang struktur retorika dan fitur linguistik bagian pendahuluan artikel jurnal penelitian berbahasa Indonesia dalam bidang ilmu kedokteran dan kesehatan sehingga dapat meminimalkan permasalahan yang dihadapi dalam menyusun dan menulis bagian pendahuluan artikel jurnal penelitian.

\section{DAFTAR PUSTAKA}

Budiharso, Teguh. 2006. Panduan Lengkap Penulisan Karya IImiah. Dirjen Dikti dan LPPMU Universitas Mulawarman. Samarinda: LPPM Universitas Mulawarman.

Chaer, Abdul. 2007. Lingustik Umum. Jakarta: Rineka Cipta.

Darma, Aliah Yoce. 2009. Analisa Wacana Kritis. Bandung: Yrama Widya.

Djajasudarman, Fatimah. 2012. Wacana dan Pradigmatik. Bandung: Refika Aditama.

HP, Achmad. 2010. Paradigma dan Pendekatan Analisis Wacana Jakarta: Program Pascasarjana Universitas Negeri Jakarta.

Keraf, Gorys. 1994. Diksi dan Gaya Bahasa. Jakarta: Gramedia Pustaka Utama. 
Muhtadin, 2014, Analisis Struktur Retorika dan Fitur Linguistik bagianpendahuluanArtikel Jurnal Penelitian Dalam Bidang Hukum. Bengkulu: Universitas Bengkulu.

Murti, 2014. Analisis Struktur Retorika Dan Fitur Linguistik Dalam Bidang Linguistik. Bengkulu: Universitas Bengkulu.

Ramlan, M. IlmuBahasa Indonesia: Sintaktis, Cet. Ke 7, UP. Karyono, Yogyakarta, 1985.

Safnil dan Dian Eka Chandra Wardhana. 2013. Analisis Struktur Retorika dan Fitur Linguistic Teks Bagian Pendahuluan Artikel Jurnal Penelitian berbahasa Indonesia Dalam Berbagai Bidang IImu. Bengkulu. Usulan penelitian tim pascasarjana Universitas Bengkulu.

Safnil. 2014. Menulis Artikel Jurnal Internasional dengan Gaya Bahasa Inggris. Bengkulu: FKIP Unib Press
Safnil. 2001. Rhetorika Structure Analysis of The Indonesia Research Articles, Unpublished The Australian National University Canberra Australia.

Safnil. 2010. Pengantar Analisis Retorika Teks. Bengkulu: FKIP UNIB Pess.

Sobur, Alex. 2009. Analisis Teks Media. Bandung: Rosda.

Sudjana, Nana. 1991. Tuntunan Penyusunan Karya Ilmiah. Bandung. Sinar Baru.

Sukardi, 2009. Metodelogi Penelitan Pendidikan. Jakarta: Bumi Aksara.

Sukino, 2004. Memahami Wacana Bahasa Indonesia. Bengkulu: Unib Press.

Susetyo. 2009. Menulis Akademik. Bengkulu: FKIP UNIB.

Tjiptadi, Bambang dan Negoro, ST. 1985. Tata bahasa Indonesia. Semarang: Yudhistira. 